\title{
The nonspecific DNA-binding and -bending proteins HMG1 and HMG2 promote the assembly of complex nucleoprotein structures
}

\author{
Tanya T. Paull, ${ }^{1}$ Michael J. Haykinson, ${ }^{2}$ and Reid C. Johnson ${ }^{1-3}$ \\ ${ }^{1}$ Molecular Biology Institute, University of California Los Angeles, Los Angeles, California 90024 USA; ${ }^{2}$ Department \\ of Biological Chemistry, University of California Los Angeles (UCLA) School of Medicine, Los Angeles, California \\ 90024-1737 USA
}

\begin{abstract}
The mammalian high mobility group proteins HMG1 and HMG2 are abundant, chromatin-associated proteins whose cellular function is not known. In this study we show that these proteins can substitute for the prokaryotic DNA-bending protein HU in promoting the assembly of the Hin invertasome, an intermediate structure in Hin-mediated site-specific DNA inversion. Formation of this complex requires the assembly of the Hin recombinase, the Fis protein, and three cis-acting DNA sites, necessitating the looping of intervening DNA segments. Invertasome assembly is strongly stimulated by HU or HMG proteins when one of these segments is shorter than $104 \mathrm{bp}$. By use of ligase-mediated circularization assays, we demonstrate that HMG1 and HMG2 can bend DNA extremely efficiently, forming circles as small as $66 \mathrm{bp}$, and even 59-bp circles at high HMG protein concentrations. In both invertasome assembly and circularization assays, substrates active in the presence of HMG1 contain one less helical turn of DNA compared with substrates active in the presence of HU protein. Analysis of different domains of HMG1 generated by partial proteolytic digestion indicate that DNA-binding domain $B$ is sufficient for both bending and invertasome assembly. We suggest that an important biological function of HMG1 and HMG2 is to facilitate cooperative interactions between cis-acting proteins by promoting DNA flexibility. A general role for HMG1 and HMG2 in chromatin structure is also suggested by their ability to wrap DNA duplexes into highly compact forms.
\end{abstract}

[Key Words: HMG proteins; HU; DNA bending; site-specific recombination]

Communication between proteins bound to closely positioned sites on a DNA molecule, with the requisite looping of the intervening DNA segment, is a common feature of many biological reactions (for review, see Echols 1986; Ptashne 1986; Adhya 1989). When the intervening segment is very short, interactions between proteins bound at these sites may be inhibited as a result of the inherent stiffness of DNA. This inflexibility has been demonstrated by ligation assays showing that the minimal length of DNA that can form a circle is $\sim 150 \mathrm{bp}$ (Shore et al. 1981). DNA segments shorter than this cannot circularize without the aid of additional factors or sequences that serve to increase flexibility. Accessory proteins that fulfill this role may be important in regulating synergistic interactions between proteins bound to sites within complex regulatory elements.

Although little is currently known about such factors in eukaryotic systems, proteins have been described in prokaryotic systems that function specifically to promote cooperative interactions between cis-acting ele-

${ }^{3}$ Corresponding author. ments. The sequence-specific binding and bending protein, integration host factor (IHF), has been shown to promote interactions between high- and low-affinity integrase-binding sites in intasome assembly during phage $\lambda$ site-specific recombination (Richet et al. 1986; Moitoso de Vargas et al. 1989; Kim et al. 1990), between DnaA proteins bound within the pSC10l replication origin (Stenzel et al. 1991), and between transcriptional activators and $\sigma^{54}$ RNA polymerase (Gober and Shapiro 1990; Hoover et al. 1990). In the case of $\lambda$ intasome assembly, an intrinsically bent DNA sequence or an unrelated DNA-bending protein can substitute for IHF binding, demonstrating that the ability of IHF to bend DNA is its principal function in this system (Goodman and Nash 1989; Goodman et al. 1992).

A related but nonspecific DNA-binding protein in prokaryotes, HU, strongly stimulates Hin-mediated sitespecific recombination under certain conditions (Johnson et al. 1986; Haykinson and Johnson 1993). In this DNA inversion reaction, the Hin recombinase binds to sites located at either end of the invertible DNA segment on a supercoiled DNA molecule (Glasgow et al. 1989; Johnson 1991). The two Hin-bound hix sites synapse at 
the recombinational enhancer, which is bound at two sites by dimers of the Fis protein. This invertasome structure (Fig. 1) has been directly visualized by immunoelectron microscopy (Heichman and Johnson 1990). The formation of the invertasome is required to initiate DNA strand exchange, which is believed to occur by a rotation of Hin subunits after double-stranded cleavage and covalent attachment to the DNA at the center of the hix sites (Kanaar et al. 1990; Heichman et al. 1991). The cis-acting Hin recombinational enhancer can be assembled into the invertasome when positioned over $4 \mathrm{~kb}$ from a hix site. Invertasome assembly in reactions containing just the Hin and Fis proteins, however, is inefficient when $<104 \mathrm{bp}$ is present between the center of the closest hix site (hixL1 in Fig. 1) and the center of the proximal Fis-binding site on the enhancer (Haykinson and Johnson 1993). In the presence of the HU protein, invertasome assembly occurs both in vitro and in vivo with intervening DNA segments as short as $60 \mathrm{bp}$, provided the hix and enhancer sites are in the correct helical phase with respect to each other. By binding within the short intervening segment, $\mathrm{HU}$ is believed to mediate sufficient bending of the DNA to enable the physical association of hixL1 with the enhancer.

HU is an abundant and highly conserved protein in prokaryotes (for review, see Drlica and Rouvière-Yaniv 1987; Pettijohn 1988). In Escherichia coli, there are an estimated 30,000 heterodimers per cell, with each dimer comprised of two highly related subunits. In addition to its function in Hin-mediated DNA inversion, HU has been shown to play important roles in other specific reactions such as phage $\mathrm{Mu}$ transposition (Craigie et al. 1985), Tn10 transposition (Morisato and Kleckner 1987), and chromosomal DNA replication (Dixon and Kornberg 1984). A general role in mediating chromosome compaction in the bacterial nucleoid has also been implicated, although mutants deficient in the synthesis of both subunits remain viable (Rouvière-Yaniv et al. 1979; Wada et al. 1988; Huisman et al. 1989).
Although $\mathrm{HU}$ is the only protein from $E$. coli that can promote Hin invertasome assembly with short intervening segments, we found that an activity is also present in mammalian nuclear extracts that can efficiently substitute for HU (Haykinson and Johnson 1993). In this study, we have used the Hin inversion reaction as an assay for general eukaryotic factors that can facilitate cooperative interactions between cis-acting proteins. We show that the abundant chromatin-associated high mobility group (HMG) proteins 1 and 2, like $\mathrm{HU}$, can promote invertasome assembly irrespective of DNA sequence. By ligasemediated circularization of short DNA fragments, we demonstrate that HMG1 and HMG2 can bend DNA extremely efficiently, generating smaller DNA circles than is possible with HU. Finally, we examine the activity of isolated structural domains of HMGl with respect to invertasome assembly and DNA bending.

\section{Results}

HMG proteins in HeLa nuclear extract can substitute for $\mathrm{HU}$ in invertasome assembly

In our initial search for eukaryotic proteins that could substitute for $\mathrm{HU}$ in the Hin inversion reaction, we used reaction conditions that result in invertasome assembly without strand exchange (Johnson and Bruist 1989). Incubation of a plasmid substrate with Hin and Fis in the absence of $\mathrm{Mg}^{2+}$ and the presence of ethylene glycol results in the accumulation of invertasome structures, as measured by double-strand cleavage by Hin within both recombination sites. We have shown previously that invertasome assembly on a plasmid containing 83 bp between hixL1 and the enhancer is very inefficient unless HU is present (Haykinson and Johnson 1993). As shown in Figure 2A, a nuclear extract derived from HeLa cells efficiently substituted for $\mathrm{HU}$ in promoting Hin-mediated DNA cleavage, as evidenced by the release of invertible DNA segment from the vector. At a high protein concentration the activity is masked by strong topoi-

Figure 1. The Hin-mediated DNA inversion reaction. A schematic model is shown for the initial supercoiled substrate (left), the Hin invertasome (center), and the rearranged product (right). The recombination substrates used in this study contain the enhancer located between the Hinbinding sites (hixL1 and hixL2), but much closer to hixL1 (40-96 bp) than to hixL2 (703 bp). The hix sites bound by Hin recombinase dimers (hatched spheres) are associated together at the enhancer, which is bound by two Fis dimers (solid ellipses). HU (solid triangles) or as shown in this paper, HMG1 and HMG2, facilitate this process when the separation between a hixL site and the enhancer is short $K<100$ bp). The precise locations and stoichiom-
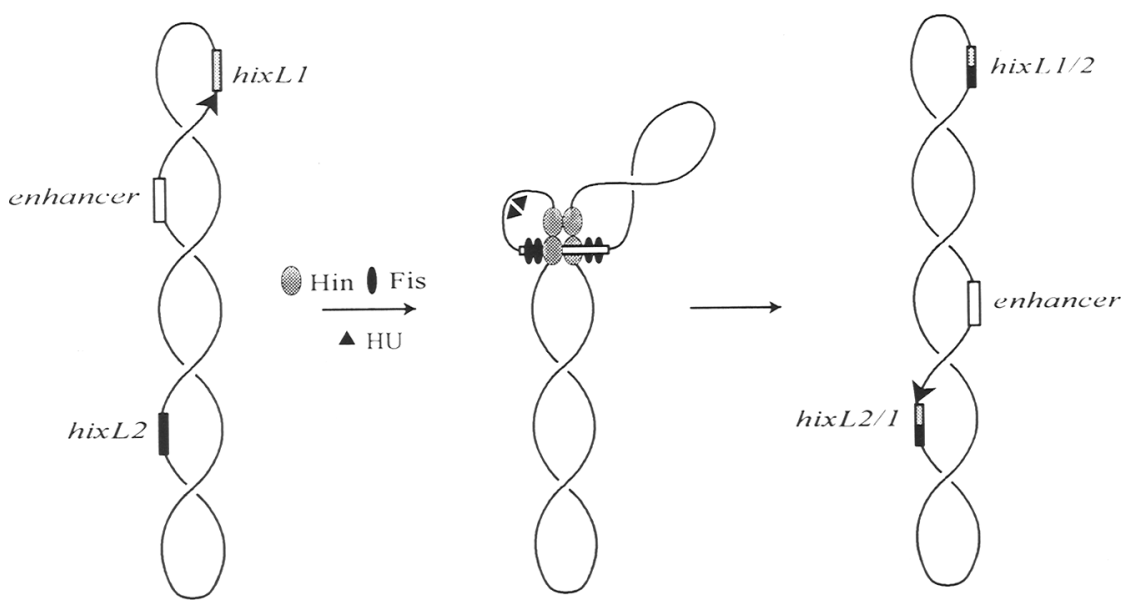
etry of proteins within this complex are not known. The Hin recombinase cleaves and exchanges the DNA strands, resulting in the inversion of the DNA segment between the hix sites. 
A
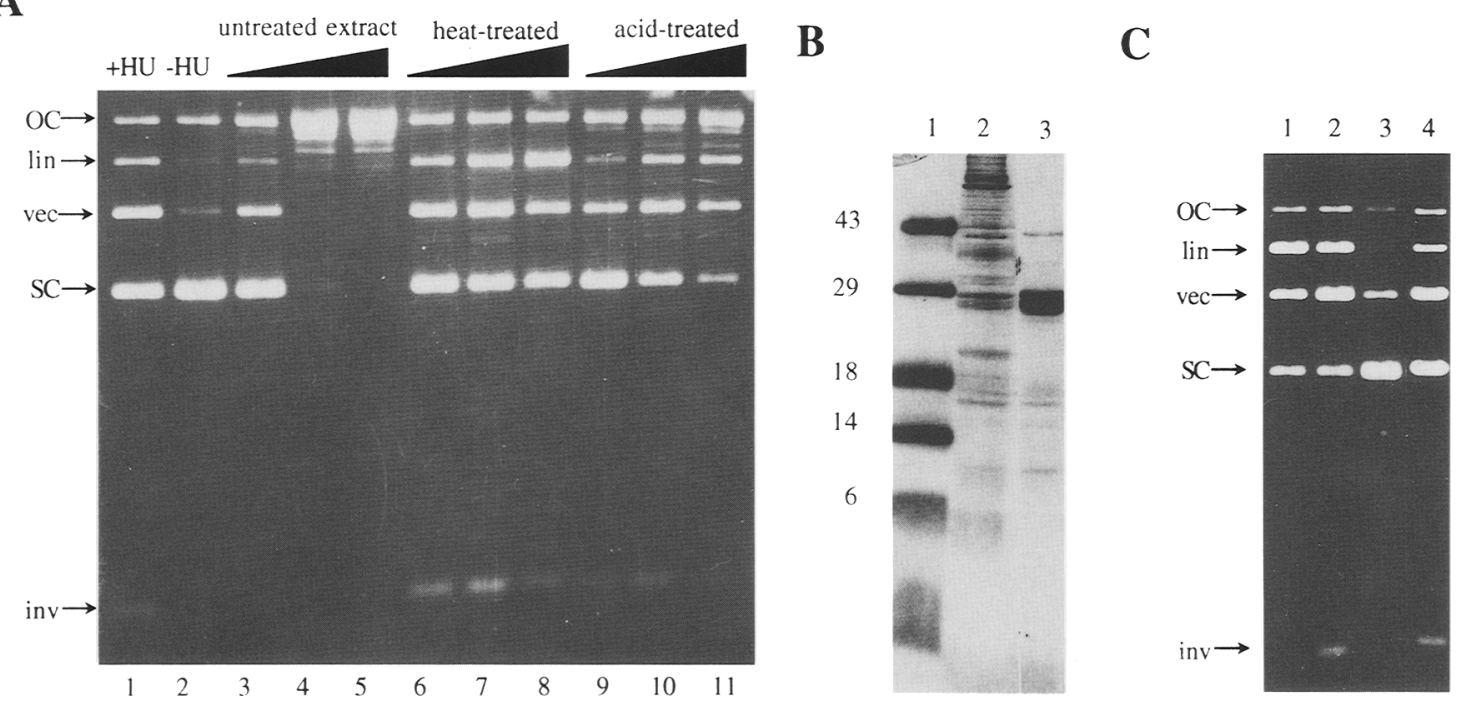

Figure 2. Activity of HeLa nuclear extract in the cleavage reaction. $(A)$ Shown are Hin cleavage reactions using pMS551-83, which has 83 bp between hixL1 and the enhancer. Reactions were performed with Hin, Fis, and either HU (lane 1; $100 \mathrm{ng}$ ), buffer only (lane 2), untreated HeLa nuclear extract (lanes $3-5 ; 0.1,0.5,2.5 \mu \mathrm{g}$ ), nuclear extract heated at $80^{\circ} \mathrm{C}$ for $15 \mathrm{~min}(\mathrm{lanes} 6-8 ; 0.1,0.5,2.5 \mu \mathrm{g}$ ), or nuclear extract incubated for $30 \mathrm{~min}$ with $0.1 \mathrm{~N} \mathrm{HCl}$ followed by neutralization with $0.1 \mathrm{~N} \mathrm{NaOH}(\mathrm{lanes} 9-11 ; 0.1,0.5,2.5 \mu \mathrm{g})$. Arrows indicate the locations of the invertible segment (inv), vector (vec), and linear plasmid (lin) bands that are the products of Hin cleavage, along with the supercoiled $(\mathrm{SC})$ and open circular forms $(\mathrm{OC})$ of the substrate plasmid. (B) SDS-PAGE of HeLa nuclear extract and HeLa HMG proteins. Molecular weight standards (lane 1), $2 \mu \mathrm{g}$ of nuclear extract (lane 2), and 1.125 $\mu \mathrm{g}$ of crude HMGs from the same extract (lane 3) were electrophoresed on a 15\% SDS-polyacrylamide gel and stained with Coomassie blue. (C) Cleavage reactions with pMS551-83 performed in the presence of HeLa HMG proteins. The plasmid was incubated with Hin, Fis, and $225 \mathrm{ng}$ of crude HMGs from the HeLa extract (lane 1), $200 \mathrm{ng}$ of heat-treated nuclear extract (lane 2), buffer only (lane 3), or proteins from the $\sim 29-\mathrm{kD}$ doublet HMG band, which were excised, eluted, and renatured from an SDS-polyacrylamide gel (lane 4; see major bands in $B$ lane 3).

somerase activities present in the extract, but strong stimulation is seen at the lowest concentration (lane 3). The HeLa activity was found to be resistant to heat inactivation $\left(80^{\circ} \mathrm{C}\right.$ for $15 \mathrm{~min}$, lanes $\left.6-8\right)$ or acid treatment $(0.1 \mathrm{~N} \mathrm{HCl}$ for $30 \mathrm{~min}$, lanes 9-11) which largely inactivate the topoisomerase. The specific activity of the heattreated nuclear extract was three to five times greater than the specific activity of heat-treated bacterial extracts as assayed by Hin-mediated cleavage (data not shown).

To identify the source of HU-like activity in the nuclear extract, heat-treated preparations were fractionated by gel filtration, ion-exchange, and reverse-phase chromatography and assayed using the Hin cleavage reaction. During the course of these experiments, the activity was always associated with a doublet of proteins migrating at $\sim 29 \mathrm{kD}$ on denaturing polyacrylamide gels (data not shown). Given these results, we reasoned that good candidates for the source of the activity in the HeLa extracts are a subset of the HMG proteins. HMG1 and HMG2, like $\mathrm{HU}$, are relatively abundant, bind DNA without sequence specificity, and resist heat and acid treatment (Shooter et al. 1974; Goodwin et al. 1975; Johns 1982; Kuehl et al. 1984; Drlica and Rouvière-Yaniv 1987). HMG1 and HMG2 are $\sim 25 \mathrm{kD}$ in molecular mass but migrate at $\sim 29 \mathrm{kD}$ on SDS-polyacrylamide gels. We therefore isolated crude HMG proteins from the HeLa extract using a protocol involving perchloric acid extraction and acetone precipitation (Johns 1982) and found that these were fully active in the cleavage reaction (Fig. $2 \mathrm{~B}, \mathrm{C}$ ). The doublet of proteins migrating at $\sim 29 \mathrm{kD}$ were excised from an SDS-polyacrylamide gel, eluted, renatured after treatment with guanidine hydrochloride, and found to be still active in our assay (Fig. 2C, lane 4). This result strongly implies that human HMG1 and HMG2 can substitute for HU in the formation of the invertasome complex.

Purified bovine HMG1, HMG2, and HMG3 can
substitute for HU in the inversion reaction

Mammalian HMG proteins are known to be almost completely conserved, with bovine HMGl containing just one amino acid difference from its human counterpart (Kaplan and Duncan 1988; Wen et al. 1989). To obtain larger amounts of material for further characterization, pure HMG proteins were obtained from bovine thymus tissue. Crude HMG protein was extracted from chromatin using trichloroacetic acid (TCA) and acetone precipitations (Goodwin et al. 1973) and pure HMG1 and HMG2 were obtained by ion exchange chromatography on polybuffer exchange resin. A major degradation product of bovine HMG1, called HMG3, which lacks the acidic tail of HMG1 (see below; Johns 1982), was isolated by a combination of ion-exchange and reverse-phase chromatography. HMG14, a protein related to HMG1 and HMG2 in terms of solubility and chromatin association, but not by sequence (Bustin et al. 1990), was also 
partially purified by similar methods as HMG3. The identities of all of these purified proteins were confirmed by amino acid analysis, and HMG1 and HMG2 were distinguished by amino-terminal amino acid sequencing (data not shown).

Purified HMG1, HMG2, HMG3 and HU were assayed for their ability to stimulate Hin-mediated inversion using a substrate containing 96 bp between the enhancer and hixL1 site (Fig. 3A). HMG1 and HMG2 had very similar activities, and both seemed to be more efficient than $\mathrm{HU}$ in promoting inversion, especially at low protein concentrations where up to 2.5-fold higher inversion rates are obtained with the HMG proteins as compared with HU (Fig. 3A and data not shown). HMG3 was also active, although to a slightly lesser extent than HMG1 and HMG2, demonstrating that the acidic tail of HMG1 is not necessary for HU-like function. In Figure $3 \mathrm{~B}$, we compare the efficiency of HMGl and HMG2 in the Hin cleavage assay with a substrate containing an 83-bp intervening segment. As discussed above, this assay measures only the ability of the HMG proteins to facilitate assembly of the invertasome without requiring that the DNA strands be exchanged and is more easily quantitated. The activities of HMG1 and HMG2 are indistinguishable in this assay, yielding a sevenfold stimulation in levels of cleaved DNA molecules. Determination of precise stoichiometry is not possible from these experiments, but the fact that the rate of invertasome assembly on 0.1 pmole of substrate DNA increases with $<0.1$ pmole of HMG protein suggests that only one or a few monomers of HMG1 or HMG2 per DNA substrate may be sufficient. These results are very similar to what we have reported previously for $\mathrm{HU}$ (Haykinson and Johnson 1993).
The ability of HMGl to assemble invertasomes on substrates containing different lengths of intervening DNA was also measured. The results for substrates in which hixL1 and the enhancer are in the optimal helical alignment with respect to each other are depicted in Figure 4A. We find that HMGl is able to promote invertasome assembly with shorter lengths of DNA between the cis-acting sites than HU. HMG1 increases the rate of invertasome assembly with a 51-bp intervening segment approximately seven-fold, whereas no stimulation is obtained at this length in the presence of HU. The rate of invertasome assembly with a 63-bp intervening segment is $\sim 50 \%$ greater with HMG1 than HU. Neither protein can promote invertasome assembly on a substrate containing a 40-bp intervening segment, and equivalent stimulation is seen at 73 bp or greater separation between hixL1 and the enhancer.

The DNA substrates used in the cleavage and inversion reactions described above contain several A-tractsshort runs of $A$ or $T$ nucleotides sequentially on one strand-in the intervening segment between the hix L1 and the enhancer. Because A-tracts are associated with intrinsically curved DNA (for review, see Travers and Klug 1990; Hagerman 1992), and some members of the HMG protein family-HMGI/Y and chicken HMG2aare known to preferentially bind to AT-rich regions of DNA (Brown and Anderson 1986; Solomon et al. 1986; Russnak et al. 1988; Thanos and Maniatis 1992), we wanted to determine whether the A-tracts in our recombination substrates influence the function of HMG proteins in these assays. For this purpose we used a substrate whose intervening segment is $63 \%$ GC-rich and contains only two AA or TT dinucleotides (pMS55197.1). As shown in Figure 4B, the rates of inversion ob-

A

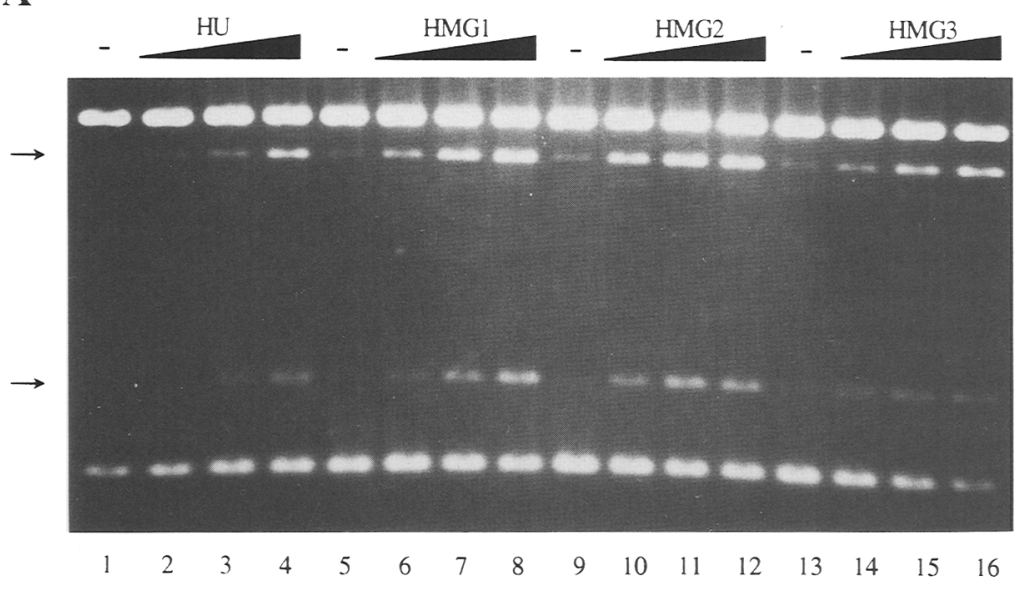

B

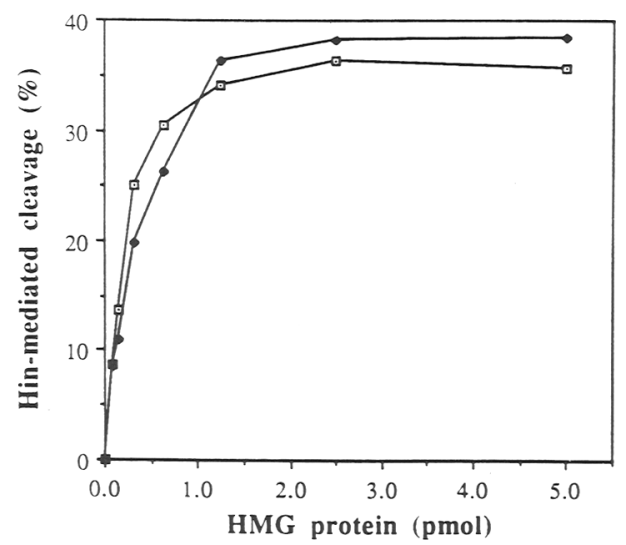

Figure 3. Activity of purified bovine HMG proteins in Hin-mediated recombination. $|A|$ Inversion reactions with 0.1 pmole of pMS551-96 and purified HMG or HU proteins are shown. Inversion reactions were performed for 4 min with Hin, Fis, and buffer only (lanes 1,5,9,13), HU (lanes 2-4), HMG1 (lanes 6-8), HMG2 (lanes 10-12), or HMG3 (lanes 14-16). Protein/DNA molar ratios for each protein used were $2: 1,10: 1$, and $50: 1$, respectively (note that 1 molecule of $H U=1 \alpha / \beta$ dimer). Arrows point to bands indicative of inversion. (B) Cleavage reactions with 0.1 pmole of pMS551-83. Reactions were performed for 4 min in the presence of varying amounts of HMG1 $(\square)$ or HMG2 ( ) as indicated. The background reaction $(\sim 20 \%)$ determined for each substrate in the absence of accessory factor was subtracted from each point shown. 
A

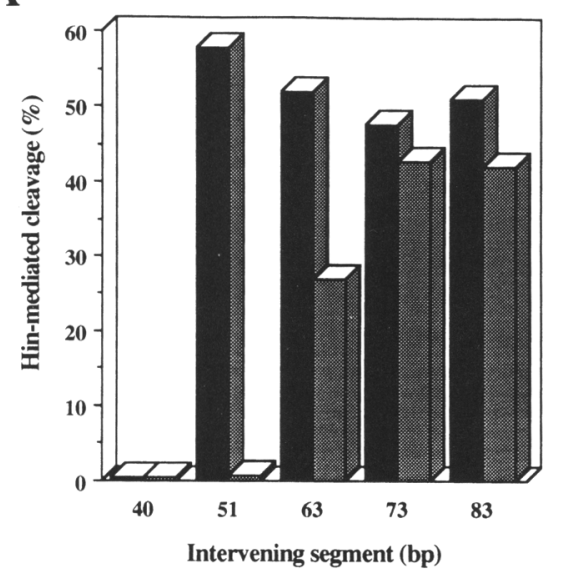

B

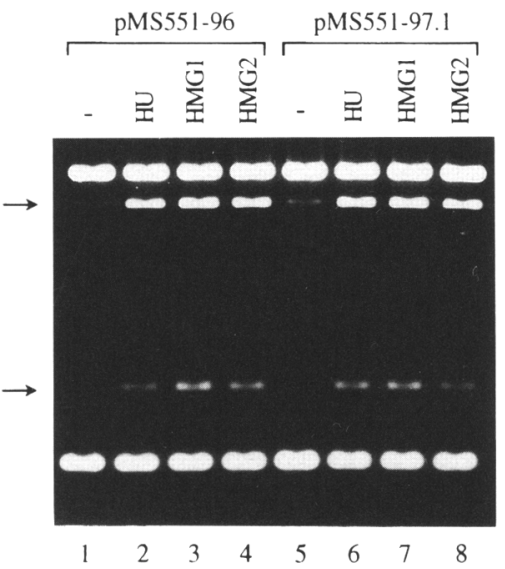

Figure 4. Activity of $\mathrm{HU}$ and $\mathrm{HMG}$ proteins on different recombination substrates. (A) HMGl and HU stimulation of invertasome assembly with intervening segments of different lengths. pMS551-40, pMS551-51, pMS551-63, pMS551-73, and pMS551-83 were used in 4-min Hin cleavage reactions in the presence of $150 \mathrm{ng}$ of HMGl (solid bar), or $150 \mathrm{ng}$ of $\mathrm{HU}$ (stippled bar). Background levels of invertasome assembly ranging from $10 \%$ to $20 \%$ cleavage obtained in the absence of accessory protein were subtracted from each point. $(B)$ Inversion reactions with pMS551-96 vs. pMS551-97.1, which has an unrelated GCrich sequence between hixL1 and the enhancer. The plasmids were incubated for 4 min with Hin, Fis, and buffer only (lanes $1,5), 100 \mathrm{ng}$ of $\mathrm{HU}$ (lanes 2,6), $100 \mathrm{ng}$ of HMGl (lanes 3,7), or 100 ng of HMG2 (lanes 4,8).

served with the substrates lacking the A-tracts were comparable to those containing the A-tracts, for HMGl, HMG2, and HU. Thus, in this assay, A-tracts do not seem to contribute significantly to the assembly functions of these proteins.

\section{HMG1 and HMG2 bend DNA}

As diagramed in Figure 1, the invertasome is a topologically complex structure, involving precise arrangement of DNA strands as well as multiple protein-protein interactions. The HMG proteins could be promoting inver- tasome assembly by binding to specific DNA structures, by directly stabilizing protein complexes, or by facilitating looping of the DNA between protein-binding sites. To investigate the latter possibility, we employed a ligation assay that has been used by others to demonstrate DNA-bending activity (Kotlarz et al. 1986; Dripps and Wartell 1987; Zahn and Blattner 1987; Hodges-Garcia et al. 1989; Schroth et al. 1989). In this assay, bending is measured by the circularization of a DNA substrate shorter than the average persistence length $(\sim 150 \mathrm{bp})$, which will not circularize in the absence of DNA-bending protein. The protein is incubated with ${ }^{32} \mathrm{P}$-labeled DNA fragments at low concentrations, which favor intramolecular reactions, and then with T4 DNA ligase. Monomer DNA circles form during the reaction at a rate dependent on the concentration of protein and the ability of the protein to bend DNA. To differentiate between linear and circular molecules, the DNA is then incubated with exonuclease III, which digests linear but not circular ligation products.

HMGl, like HU (Hodges-Garcia et al. 1989), is very efficient in promoting the formation of monomer circles in the ligation assay (Fig. 5A). The initial 99-bp fragment is shown in lane 1 with no added protein, and in lane 2 with the addition of ligase-yielding dimer linear, dimer circular, and a trace of trimer linear species. The DNA in lane 3 was incubated with ligase and then with exonuclease III; thus, the linear ligation products are absent, whereas the dimer circle band remains. In the rest of the lanes, the DNA was incubated with increasing amounts of either HU (lanes 4-8) or HMG1 (lanes 9-13) before addition of ligase. Both proteins can efficiently promote formation of 99-bp monomer circles, which do not form in the absence of DNA-bending protein. Note that in all of the reactions with HU and HMG1, exonuclease III was used after ligation; thus, all of the bands seen are circular molecules. At this DNA concentration, monomer circles appear at a protein/DNA molar ratio of $4: 1$ (lanes 5,10), and levels appear to be maximal at a ratio of $8: 1$ with HMG1 (lane 11) and 16:1 with HU (lane 7). At higher concentrations of HU or HMG1 the levels of dimer circle decrease in favor of increased levels of monomer circle until the monomer species comprises $100 \%$ of the circular molecules.

As shown in Figure 5B, HMG2 and HMG3 are also active in the ligation assay. Levels of monomer circles seen with HMG2 are nearly identical to those seen with HMG1, whereas HMG3 is less active. As in the inversion assay, HMG14 shows no activity (not shown). Thus, the results of the ligation assays parallel the results of the cleavage and inversion assays and provide evidence that the function of HMG1 and HMG2 in promoting assembly of the invertasome complex may be to promote bending of the DNA substrate.

\section{Distance dependence of DNA circularization mediated by HMG1 and HU}

As mentioned above, the intrinsic torsional stiffness of short DNA fragments, as well as their helical repeat, 
Paull et al.

A

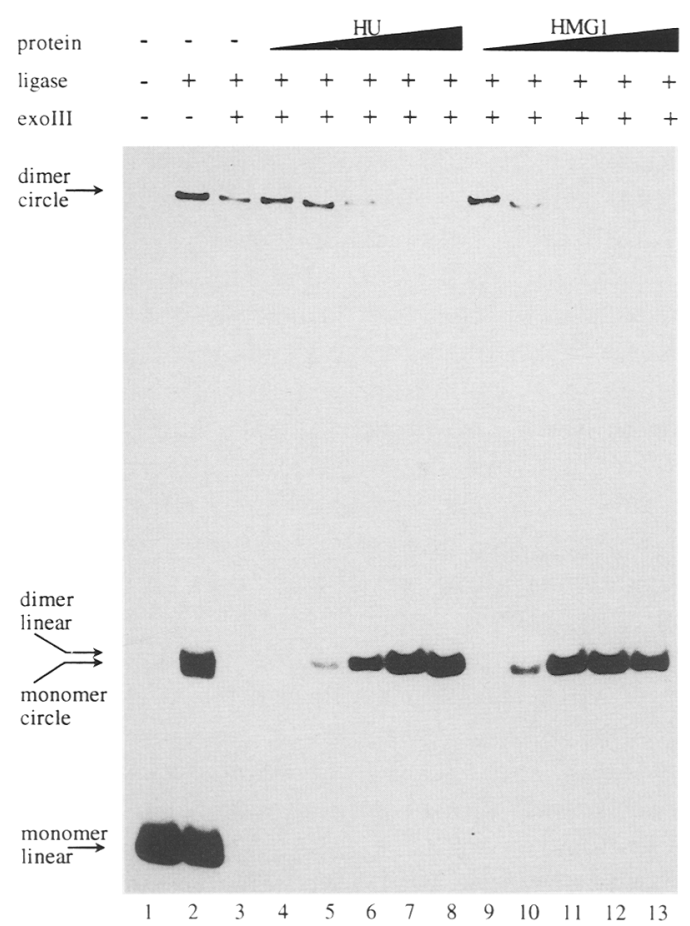

B

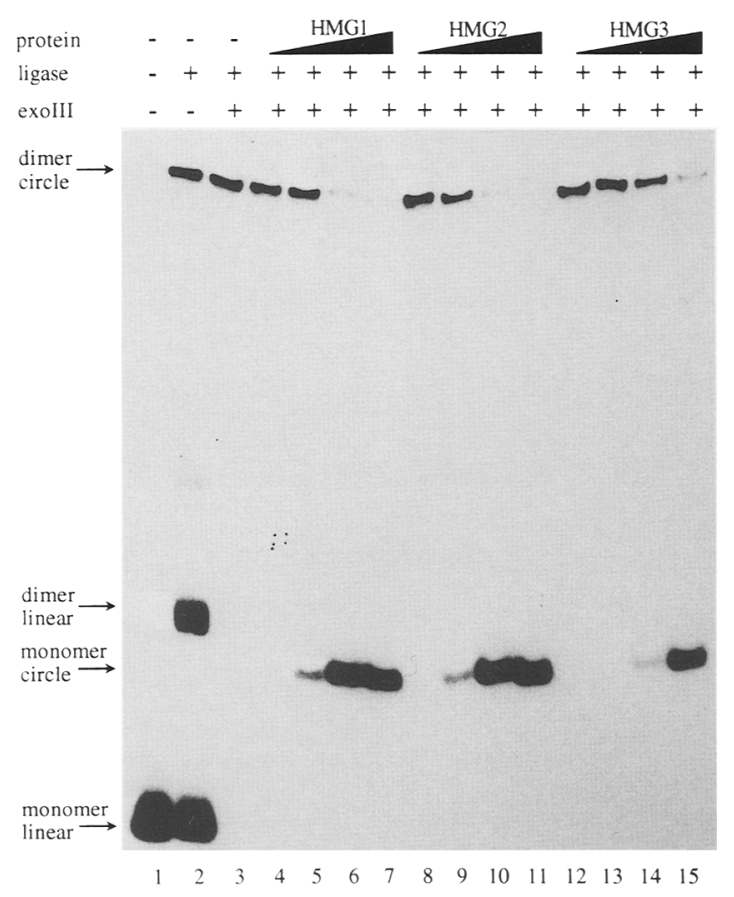

Figure 5. Circularization of 99 bp of DNA promoted by HU, HMG1, HMG2, and HMG3. (A) A 99-bp ${ }^{32}$ P-labeled DNA fragment with EcoRI sticky ends was incubated with buffer only (lanes 1-3), HU (lanes 4-8), or HMG1 (lanes 9-13). T4 DNA ligase was added to reactions in lanes $2-13$ and incubated at $30^{\circ} \mathrm{C}$ for $10 \mathrm{~min}$. Reactions in lanes 3-13 were subsequently incubated with exonuclease III to remove linear ligation products. The reaction products were electrophoresed on a $7 \%$ polyacrylamide gel, which was then dried and autoradiographed. Protein/DNA molar ratios used were $2: 1$ (lanes 4,9), $4: 1$ (lanes 5,10), $8: 1$ (lanes 6,11), 16:1 (lanes 7,12), and 32:1 (lanes 8,13). (B) HMG1, HMG2, and HMG3 were used in ligation reactions as described in part $A$. Protein/DNA ratios used were $2: 1$ (lanes 4,8,12), $4: 1$ (lanes 5,9,13), $8: 1$ (lanes 6,10,14), and $16: 1$ (lanes 7,11,15). Note that the migration of the monomer circle species is variable in relation to the migration of the dimer linear species depending on the voltage used during electrophoresis.

impose constraints on DNA looping which may, in theory, be altered by DNA-bending proteins. To examine the effects of HMG1 and HMG2 on the efficiency of DNA circularization as a function of DNA length, we constructed a series of ligation substrates ranging from 59 to $99 \mathrm{bp}$, varying by one or a few base pairs at each step.

Efficient formation of monomer circles in reactions containing HMG1 (Fig. 6A) and HMG2 (not shown) was observed with fragments ranging from 66 to $99 \mathrm{bp}$. Levels of monomer circles varied in an oscillatory manner from 0 to $50 \%$ of total DNA, presumably in response to the strict requirement for an integral number of turns in a small DNA circle. At HMG:DNA concentrations of $32: 1$, a small number $(4 \%)$ of 59 -bp circles was obtained. Fourier analysis of the periodicity at HMG1/ DNA ratios of $8: 1,16: 1$, and $32: 1$ gave an average repeat of $10.6-10.7$ bp per turn, consistent with the average helical repeat of linear DNA of $\sim 10.5$ bp per turn determined by a variety of methods (Bellomy and Record 1990).

For comparison, a similar analysis was performed on HU. HU has been shown previously to promote circularization of a 99-bp fragment (Hodges-Garcia et al. 1989). We find that HU promotes circularization of fragments as small as $78 \mathrm{bp}$, and the pattern of activity also seems to reflect the helical repeat of linear DNA (Fig. 6A). Unlike HMG1 and HMG2, however, HU was unable to circularize fragments shorter than $75 \mathrm{bp}$.

The various ligation fragments used in the ligation assays were generated from a set of DNA substrates that contain several A-tracts. To determine the effects of these sequences on HMG1-mediated DNA circularization, we also performed ligation assays on another set of DNA fragments. These substrates have a single A-tract located near one end of the molecule, but this would not be predicted to have a significant effect on either the overall intrinsic curvature of the DNA or on the proteininduced site-specific bending of the molecules ( $\mathrm{Wu}$ and Crothers 1984). These fragments, ranging from 60 to 76 bp, were used in ligation assays with HMGl, and the results were comparable to the original substrates in the same size range (Fig. 6B). These substrates are efficiently circularized by similar amounts of HMG1, and the same general phasing pattern is retained.

\section{Domain B of HMG1 is sufficient for bending activity}

Protease digestion experiments, secondary structure predictions, and DNA-binding studies indicate that HMG1 and HMG2 have three major structural domains (Reeck 

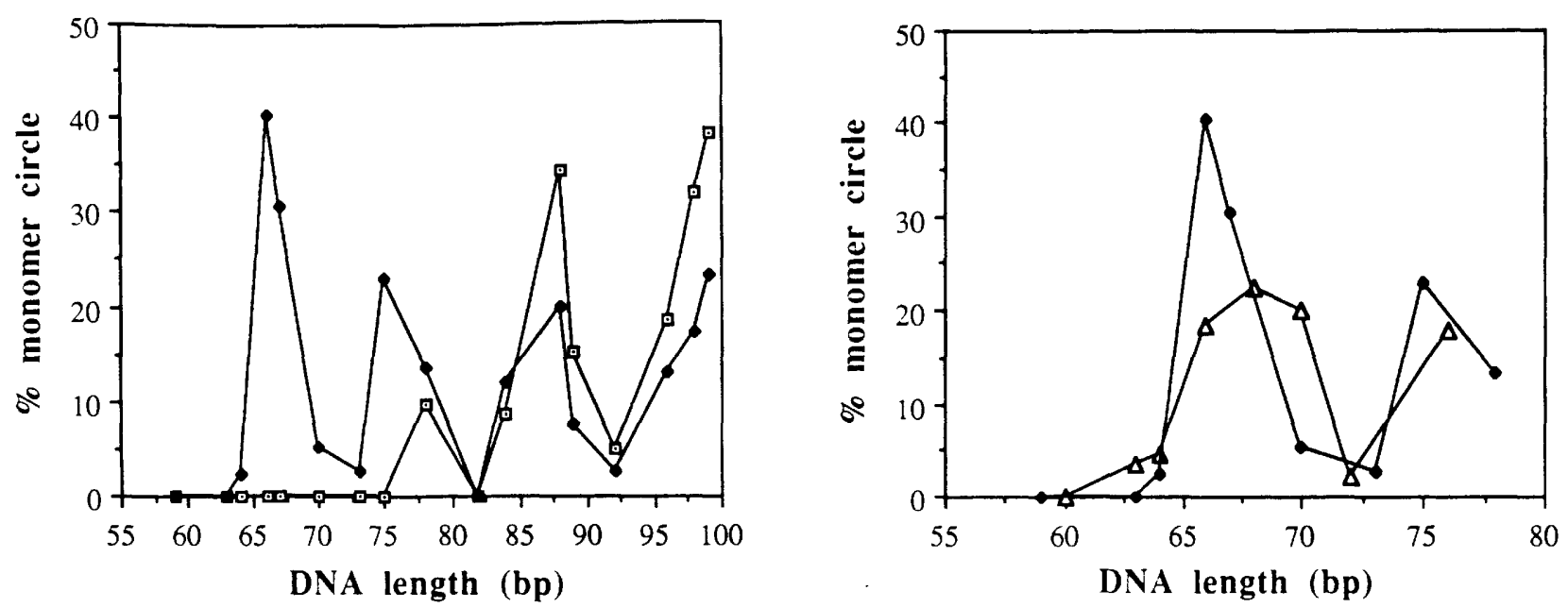

Figure 6. Circularization of 59- to 99-bp DNA fragments promoted by HMGl and HU. (A) Circularization of labeled DNA substrates ranging from 59 to $99 \mathrm{bp}$ in the presence of HMG1 $(\downarrow)$ and $\mathrm{HU}(\square)$ is shown using a protein/DNA ratio of $16: 1$. Ligation reactions were done as described in Fig. 5A, and each autoradiograph was scanned quantitatively. Percent $|\%|$ monomer circle refers to the ratio of the integrated density of the monomer circle band divided by the integrated density of the total input fragment electrophoresed in parallel. (B) Circularization of 59- to 76-bp labeled DNA substrates of different sequence in the presence of HMGl is shown. Ligation reactions were performed at a HMGl/DNA ratio of 16:1 on DNA fragments lacking centrally located A-tracts $(\Delta)$, and the results were plotted together with the data from the same range of fragment lengths from $A(\downarrow)$.

et al. 1982; Carballo et al. 1983, 1984; Bianchi et al. 1992). The DNA-binding portions of the proteins are composed of two relatively basic regions, termed domains $\mathrm{A}$ and $\mathrm{B}$, which are $\sim 47 \%$ similar but only $27 \%$ identical to each other in amino acid sequence. The carboxy-terminal portions of the proteins contain the third, extremely acidic, domain. As diagramed in Figure 7 , when HMG1 or HMG2 is incubated with low concentrations of V8 protease for a short time, intact protein fragments can be recovered that correspond roughly to the structural domains. Isolated V3 (approximately domain A) and V2 (approximately domain B) have high $\alpha$-helical content and bind duplex DNA, whereas V1 lapproximately domain B plus acidic tail) is comparatively unstructured and does not bind DNA (Carballo et al. 1983, 1984).

Figure $8 \mathrm{~A}$ shows the results of inversion assays with isolated V2 and V3 peptides. The mix of protease digestion products, containing no intact HMG1 protein, was active in stimulating Hin-mediated DNA inversion (lane 3). Of the isolated domains, only V2 (domain B) showed activity, although significantly less than that of intact HMG1. Similarly, when the digestion products were used in the ligation assay, only V2 (domain B) was active (Fig. 8B). Even though V1 contains domain B, it has been shown to be quite different from V2 alone, having very little secondary structure as measured by spectroscopic techniques (Carballo et al. 1984). This effect has been ascribed to destabilizing effects of the acidic tail on domain B when separated from domain A. V1, like V3, was not active in DNA bending (Fig. 8B) or in inversion stimulation (data not shown).
To determine whether our preparation of V3 yielded an intact peptide, we examined its ability to bind linear and branched DNA structures by use of filter-binding assays. Bianchi and co-workers have demonstrated that both domains $\mathrm{A}$ and $\mathrm{B}$ have a high affinity for cruciform DNA (Bianchi et al. 1992). Filter-binding assays were

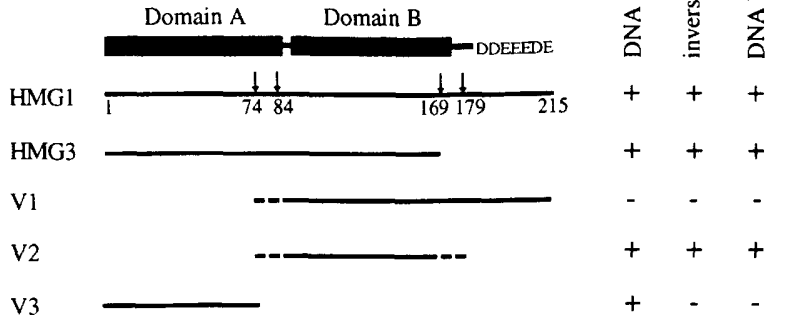

Figure 7. Domain structure of HMG1 and summary of the activities of HMGl and its proteolytic derivatives. The approximate locations of domain A (amino acids 1-89), domain B (amino acids 90-174), and the acidic tail (amino acids 186-215) of HMG1 are shown. HMG3 is a natural degradation product of bovine HMG1, which is missing the carboxy-terminal tail (Johns 1982). Partial proteolysis of HMG1 with V8 protease yields three major products: V1 (domain B and the acidic tail), V2 (approximately domain B), and V3 (approximately domain A). The locations of the amino- and carboxy-terminal positions of the peptides are based on our amino acid composition and mass spectroscopy data and the analysis of Carballo et al. (1983). The presence of residues $74-84$ and $169-179$ in V2 is variable because of multiple protease cutting sites. 


\section{B}

A

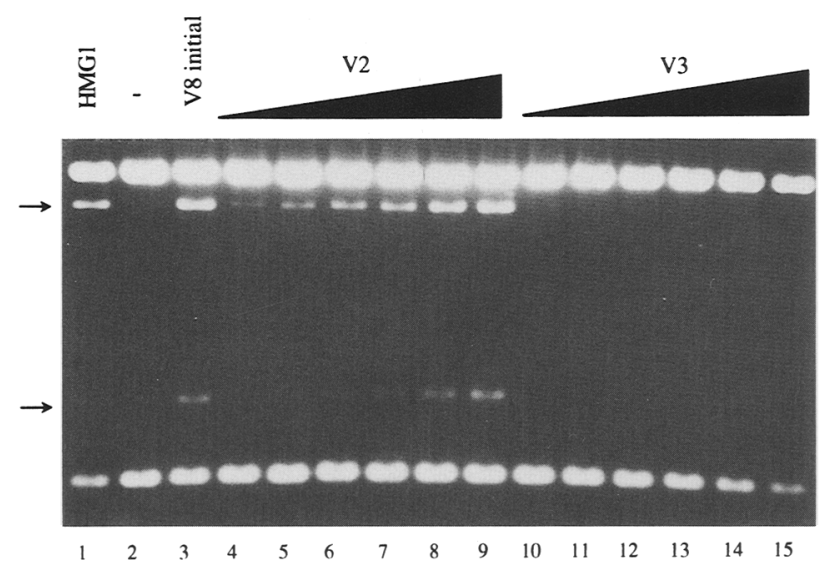

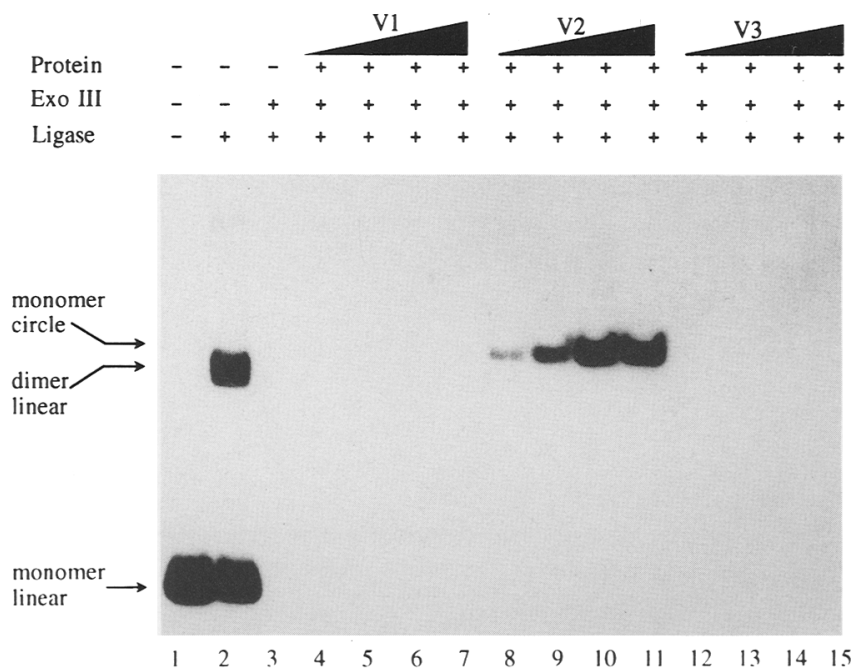

Figure 8. Activity of isolated V8 digestion products of HMG1. (A) V2 (approximately domain B) and V3 (approximately domain A) were used in the Hin inversion reaction as described in Fig. 3A. Intact HMG1 (100 ng) was added in lane 1, buffer only in lane 2, and a mix of V8 digestion products before separation (V8 initial, $1 \mu \mathrm{g}$ total) in lane 3. Amounts of isolated domains added to reactions ranged from $30 \mathrm{ng}$ to $1 \mu \mathrm{g}$ in two-fold increments as denoted. $(B)$ Ligation assays were performed on 99-bp labeled DNA fragments in the presence of V1 (approximately domain B and carboxy-terminal acidic tail), V2 (approximately domain B), and V3 (approximately domain A) as described in Fig. 5A. Protein/DNA ratios for each peptide were $4: 1$ (lanes 4,8,12), $8: 1$ (lanes 5,9,13), 16:1 (lanes $6,10,14$ ), and $32: 1$ (lanes 7,11,15). The calculated protein/DNA ratios for V2 and V3 assume that each is acting as a homodimer (Bianchi et al. 1992).

performed with HMG1, V2, and V3 in the presence of ${ }^{32}$ P-labeled Holliday junction DNA or linear DNA. Significant levels of binding to both Holliday structures and linear DNA were seen with each of the proteins tested (data not shown). We did observe, however, that our V3 preparation gave a less stable complex in mobility shift assays with Holliday junction DNA compared with V2, HMGl, and HU, although no significant difference in cruciform DNA binding between HMG1 domains was noted by Bianchi et al. (1992). Interestingly, HU gave the most stable complexes with Holliday junction DNA in mobility shift assays compared with HMG1, V2 and V3, consistent with a recent report that HU binds specifically to four-way DNA junctions (Pontiggia et al. 1993). It is possible that the physical differences between cloned domains and protease-generated domains are responsible for the apparently weaker binding of our V3 preparation in the mobility shift assays (see Discussion). Alternatively, the structural differences between cruciforms and the more dynamic Holliday junctions may account for this variance.

\section{Discussion}

In this study we demonstrate that the chromatin-associated mammalian proteins HMG1 and HMG2 exhibit activity greater than that of $\mathrm{HU}$ in stimulating DNA recombination in the Hin-mediated site-specific inversion reaction. Higher inversion rates are obtained with HMG1 and HMG2 as compared with HU, particularly when limiting accessory protein is present. When invertasome assembly was directly measured in the Hin cleavage assay, HMG1 and HMG2 were found to increase rates of invertasome assembly up to 10 -fold, depending on the DNA substrate assayed. In addition, the HMG proteins were found to promote invertasome assembly with shorter intervening segments between the enhancer and hix sites than was possible with HU. For example, whereas $\mathrm{HU}$ can promote moderate levels of invertasome assembly on DNA substrates with intervening segments of 63 bp (Haykinson and Johnson 1993), HMG1 and HMG2 can efficiently promote invertasome assembly on substrates containing just 51 bp between hix and the enhancer. Like HU, only a few molecules of HMG1 or HMG2 per supercoiled substrate are needed for stimulation.

The HMG proteins are a family of chromatin-binding proteins classified according to solubility, charge, and molecular weight (Bustin et al. 1990). HMG1 and HMG2 are abundant members of the group, present in a ratio of 0.2-0.3 molecules each per nucleosome as measured in several rat tissues (Kuehl et al. 1984). They bind doubleand single-stranded DNA with no apparent sequence specificity, although they bind with markedly higher affinity to cruciform structures (Wright and Dixon 1988; Bianchi et al. 1989) and cis-platin-modified DNA (Pil and Lippard 1992). The exact functions of HMG1 and HMG2 are not yet known, although stimulatory effects of HMG1 and HMG2 on transcription (Stoute and Marzluff 1982; Tremethick and Molloy 1986,1988; Singh and 
Dixon 1990), DNA replication (Alexandrova et al. 1984; Alexandrova and Beltchev 1988), and nucleosome assembly (Bonne-Andrea et al. 1984) have been reported. Our results with the Hin site-specific recombination reaction suggest that one specific function of HMG1 and HMG2 is to promote assembly of higher order nucleoprotein complexes, a feature that may be common to each of the processes cited above.

Although HMG proteins are not related to HU in sequence, it appears that they may play a similar functional role. HU is known to stimulate assembly of prepriming replication complexes in vitro (Baker et al. 1986; Skarstad et al. 1990), as well as the assembly of recombination intermediates in phage $\mathrm{Mu}$ transposition ( $\mathrm{La}$ voie and Chaconas 1990; Baker and Mizuuchi 1992) and Hin-mediated inversion (Johnson et al. 1986; Haykinson and Johnson 1993). The known properties of HU, HMG1, and HMG2 are distinct from their sequence-specific counterparts: IHF in bacteria and LEF1 (the clearest example) in mammals. Both IHF and LEF-1 bind and bend DNA at specific recognition sites (Robertson and Nash 1988; Thompson and Landy 1988; Yang and Nash 1989; Giese et al. 1991,1992). The binding of LEF-1 or the presence of intrinsically curved DNA can functionally substitute for IHF in the phage $\lambda$ intasome reaction /Goodman and Nash 1989; Giese et al. 1992; Goodman et al. 1992). Thus, at least in this system, IHF and LEF-1 appear to play structural roles in facilitating productive contacts between proteins bound to adjacent DNA sites. It is proposed that LEF-1 also fulfills a primarily structural role when bound in the TCR $\alpha$ enhancer /Giese et al. 1992). HU, HMG1, and HMG2 seem to perform a similar function, but without the restriction of binding to a specific DNA recognition sequence.

\section{DNA bending mediated by HMG1 and HMG2}

We find that HMG1 and HMG2 have extraordinary DNA-bending activity, as demonstrated by their ability to promote circularization of very short DNA fragments. Enhancement of the ligation frequency of two ends of a short DNA fragment has been used previously to demonstrate DNA bending by $\mathrm{HU}$ on fragments ranging from 99 to 126 bp (Hodges-Garcia et al. 1989). We demonstrate in this work that HMG1 and HMG2, as well as HU, could promote ligation of fragments $\geqslant 78 \mathrm{bp}$ in length. In contrast with $\mathrm{HU}$, however, DNA circles of $66-75 \mathrm{bp}$ could be formed efficiently in the presence of HMGl. Even circles as small as 59 bp were formed, albeit inefficiently. To our knowledge, these are the smallest DNA circles yet described. The enhanced ability of the HMG proteins to bend DNA relative to HU correlates with the ability of HMG1 to promote invertasome assembly on substrates containing 10 bp less DNA between recombination sites than is possible with HU.

The degree of DNA bending promoted by HMG1 and HMG2 in the ligation assays is even greater than that observed for DNA wound around a histone octamer. Within a nucleosome, $146 \mathrm{bp}$ of DNA is wrapped $\sim 1.8$ times around a histone core with a diameter of $\sim 86 \AA$ (Richmond et al. 1984). The average diameter of a 66-bp circle (readily formed in the presence of HMGs) is only $\sim 71 \AA$, indicating much greater bending of the DNA helix associated with HMG complexes than is present in a nucleosome.

Although HMG1 and HMG2 are dramatically bending DNA, we find no evidence for a significant change in the helical repeat. The periodicity of circularization of different length DNA fragments in the presence of HMGl as calculated by Fourier analysis was $10.6-10.7$ bp per turn, which is comparable with measurements of 10.4510.6 bp per turn helical repeat on linear DNA in vitro (Bellomy and Record 1990). This conclusion is consistent with several observations that HMG1 and HMG2 are not unwinding or destabilizing the DNA helix (Shastri et al. 1982; Butler et al. 1985; Kohlstaedt et al. 1987), but is in contrast to other reports (Javaherian et al. 1979; Yoshida 1987; Sheflin and Spaulding 1989). It is possible, however, that a change in twist exerted by a single protein on the DNA molecule may not be detected in this assay. The periodicity of HU-promoted circularization was similar to that observed for HMG1, although sufficient data were not available to calculate a statistically significant helical repeat for $\mathrm{HU}$. By measuring the efficiency of invertasome assembly, we also did not find that HU or HMGl was altering the helical repeat of supercoiled DNA (Haykinson and Johnson 1993; data not shown). A significant preference of HMG1 or HMG2 activity on AT-rich regions was also not observed by either Hin-mediated inversion or ligation assays, in contrast to a report on chicken HMG2a (Brown and Anderson 1986) and another subgroup of HMG proteins, HMGI/Y, which bind preferentially to runs of five or more A or T nucleotides (Solomon et al. 1986; Russnak et al. 1988; Thanos and Maniatis 1992).

\section{Activities of isolated polypeptides from HMG1}

Previous work has established that HMG1 and HMG2 have three major domains (see Fig. 7): the amino-terminal and central regions (domains $A$ and $B$ ), which have internal homology and can bind DNA independently (Carballo et al. 1983, 1984; Bianchi et al. 1992), and the carboxy-terminal acidic tail, which can interact with histone H1 in vitro (Carballo et al. 1983). HMG3, a degradation product of HMGl missing the acidic tail, is active in promoting invertasome assembly as well as DNA bending, demonstrating that the carboxy-terminal region is not required for these functions. Analysis of V8-generated peptides of HMG1 indicate that domain B (peptide V2) alone is sufficient for promoting DNA bending and invertasome assembly. The peptide representing domain A (V3) was not capable of promoting invertasome assembly or circularization of short DNA fragments.

The differences in DNA bending and invertasome assembly activities between the V2 and V3 peptides could be indicative of functional differences between the two DNA-binding domains. On the other hand, these differences may reflect the fact that the V3 peptide does not 
contain the entire length of domain A, because we estimate that $\sim 10$ amino acids of domain $A$ that include a conserved tyrosine residue in the degenerate consensus sequence called the HMG box (see below) are missing in the V3 peptide (see Materials and methods). This residue ( $Y 77)$ is predicted to be in the conserved face of helix III, by analogy to the recently determined nuclear magnetic resonance (NMR) structure of HMG1 domain B (Weir et al. 1993). Bianchi et al. (1992) have expressed recombinant forms of the two domains and find that both are active in cruciform binding, as measured by gel electrophoresis assays. We show that whereas the V2 and V3 peptides are both active in binding linear or Holliday junction DNA in filter binding assays, the V3 peptide displayed markedly less stable binding to Holliday junctions in gel retardation assays. Thus, V3 is not functionally and may not be physically equivalent to domain $\mathrm{A}$.

Although the ability of domain B (as well as intact HMG1 and HMG2) to mediate invertasome assembly is correlated most directly with its bending properties, we cannot rule out the possibility that the HMG proteins are functioning in the inversion reaction by stabilizing a particular DNA structure, such as the plectonemic branch, that is present in the invertasome. The cruciform binding activity demonstrated by the recombinant forms of each domain could be an expression of the same activity that we have measured in the invertasome assembly and ligation assays. An alternative model of HMG protein interactions involving direct protein-protein contacts between HMG proteins and invertasome components is unlikely because of the heterologous combination of the eukaryotic accessory factors and the prokaryotic recombination system.

\section{Biological roles of HMG1 and HMG2}

HMG proteins 1 and 2 are the founding members of a family of proteins that contain HMG boxes-regions that display sequence similarity to the 85 -amino-acid DNA-binding domains of HMGl and HMG2 (see, e.g., Jantzen et al. 1990; Diffley and Stillman 1991; Ferrari et al. 1992; Fisher et al. 1992; Giese et al. 1992). Unlike HMG1 and HMG2, however, many of these proteins bind DNA at specific recognition sites. Four of the known sequence-specific HMG box proteins: LEF-1, SRY, ste11, mtTF1, and its yeast counterpart ABF2, have been shown to bend DNA (Diffley and Stillman 1992; Ferrari et al. 1992; Fisher et al. 1992; Giese et al. 1992). Thus, HMG1 and HMG2 could be the prototypes for a wide variety of specific DNA-binding proteins whose activity may be affected by their ability to modulate DNA structure (see also Lilley 1992).

HMG1 and HMG2 could function in a variety of eukaryotic transcription, replication, or recombination reactions by promoting cooperative interactions of cis-acting DNA-binding proteins. For example, they may facilitate contacts between different proteins bound within or between complex promoter and enhancer elements. In addition to their ability to function in the Hin recombination reaction, the generality of their role in nucleopro- tein complex assembly is illustrated by their ability to function in other well-characterized prokaryotic transcription and recombination reactions involving multiple cis-acting sites. HMG1 and HMG2 can substitute for IHF in stimulating activator-dependent transcription of the nifHDK promoter by $\sigma^{54}$ holoenzyme (D. Berger and S. Kustu, pers. comm.) and at the attachment sites in the prophage excision reaction of phage $\lambda$ (A. Segall, S. Goodman, and H. Nash, pers. comm.). In addition, HMGl and HMG2 can replace $\mathrm{HU}$ in the assembly of a phage $\mathrm{Mu}$ transposition complex (B. Lavoie and G. Chaconas, pers. comm.) and can substitute for IHF and HU in certain aspects of the $\operatorname{Tn} 10$ transposition reaction ( $\mathrm{R}$. Chalmers and N. Kleckner, pers. comm.).

The ability of HMG1 and HMG2 to wrap DNA to such a remarkable degree also suggests potential roles for these proteins in chromatin condensation and packaging. The relative instability of HMG1- and HMG2-DNA complexes, as compared with nucleosome-wrapped DNA, implies that structural transitions mediated by HMG1 and HMG2 may be quite dynamic. This characteristic could be particularly important in the many processes that involve transient changes in chromatin structure.

\section{Materials and methods}

\section{Recombination and ligation substrates}

The plasmids used as substrates in the recombination assays are all described by Haykinson and Johnson (1993). They are derivatives of pMS551, which contains hixL1 and the enhancer substituted between the EcoRI and HindIII sites and hixL2 inserted at the Sall site of pBR322, as schematically shown in Figure 1. The plasmids are named by the number of base pairs between the center of hix $L 1$ and the center of the proximal Fis-binding site in the enhancer. Thus, pMS551-83 and pMS551-96 contain 83- and 96-bp intervening segments, respectively.

Ligation substrates were made using PCR on the above set of recombination plasmids using primers that incorporated EcoRI sites at the ends. Fragments were internally labeled with $\left[\alpha^{-32} \mathrm{P}\right] \mathrm{dATP}$, purified by polyacrylamide gel electrophoresis, and digested with EcoRI. DNA concentrations were estimated by comparing intensities of ethidium bromide staining of an aliquot that was electrophoresed in parallel with known amounts of DNA standards of similar size. Fragment preparations were used within a week.

\section{Proteins}

Hin, Fis, and HU were purified as described (Haykinson and Johnson 1993). HeLa nuclear extracts (a gift from M. Carey, University of California School of Medicine, Los Angeles) were prepared from a $0.15 \mathrm{M} \mathrm{KCl}$ wash of HeLa nuclei as described by Dignam et al. (1983). HMG proteins were selectively extracted from HeLa nuclei by the method described in Johns (1982). Renaturation of HMG1 and HMG2 from an SDS-polyacrylamide gel was performed essentially as described in Briggs et al. (1986) except that the acetone pellet was resuspended in $5 \mu$ l of the guanidine- $\mathrm{HCl}$ solution for $15 \mathrm{~min}$ at room temperature followed by addition of $245 \mu \mathrm{l}$ of renaturation buffer. This solution $(25 \mu l)$ was used in the cleavage assay shown in Figure 2C.

The large-scale extraction of HMG proteins from calf thymus 
was essentially as described by Goodwin et al. (1973), except that the $0.35 \mathrm{M} \mathrm{NaCl}$ extract was fractionated into $2 \%$ and $10 \%$ TCA precipitates, the $10 \%$ precipitate being the crude HMG proteins. HMG1 and HMG2 were separated on polybuffer exchange resin PBE94 (Pharmacia) as described by Adachi et al. (1990). To purify other HMG proteins not retained on the polybuffer column, the supernatant of the $10 \%$ TCA solution was made $22 \%$ in TCA, and the resulting precipitate was washed in acetone, dried, and resuspended in buffer $\mathrm{A}(10 \mathrm{mM}$ Tris- $\mathrm{HCl}$ at $\mathrm{pH} 7.8,1 \mathrm{~mm}$ DTT). Approximately $20 \mathrm{mg}$ of protein from this preparation was applied to an FPLC Mono-S column (Pharmacia) and eluted with a continuous gradient from $50 \mathrm{mM}$ to $1 \mathrm{M}$ $\mathrm{NaCl}$ in buffer A. Fractions corresponding to $0.375-0.4 \mathrm{M} \mathrm{NaCl}$ that were active in the Hin cleavage assay were applied to a HR5/10 reverse-phase FPLC column (Pharmacia) in $0.1 \%$ trifluoroacetic acid (TFA) and eluted in a continuous gradient from 0 to $100 \%$ acetonitrile in $0.1 \%$ TFA. Fractions containing HMG3 and HMG14 eluted at $\sim 30 \%$ and $\sim 10 \%$ acetonitrile, respectively. Amino acid analysis was performed on aliquots of the HMG1, HMG2, HMG3, and HMG14 preparations to confirm their identity. Amino acid sequence analysis of the aminoterminal 18 residues of HMG1 and HMG2 unambiguously identified lysine and asparagine at residue 7 of HMG1 and HMG2, respectively, which enabled these two related proteins to be distinguished. All proteins were quantified by Bradford (BioRad) assays with BSA as the standard. The amounts of HMG1 and HMG 2 estimated by the Bradford assay were within $5-10 \%$ of the amounts determined by quantitative amino acid analysis.

V8 protease digestions of HMG1 were performed essentially as described by Carballo et al. (1983). The resulting peptides were isolated by chromatography on PBE94, which retains V1, followed by chromatography on an HR5/10 FPLC column, as described above, which separates V2 from V3. The boundaries of V1, V2, V3, and HMG3 were estimated by amino acid composition analysis performed on the preparations used in this study and from the data of Carballo et al. (1983) for V1, V2, and V3 and Johns (1982) for HMG3. The molecular mass of V3 was also measured by electrospray mass spectrometry to be $8532 \pm 0.2$ daltons, which best corresponds with the predicted molecular mass of 8536 daltons for amino acids 2-74. (The amino-terminal methionine was absent in the amino-terminal sequence analysis of HMG1.) These data suggested that the carboxy-terminal boundary of $\mathrm{V} 3$ is the $\mathrm{V} 8$ recognition site at amino acid 74 and that the boundaries of the predominant V2 peptide are the V8 cleavage sites at 74 and 169 or possibly at 85 and 179 . Our amino acid composition of HMG3 matched very well with a polypeptide derived from HMGl that extends from amino acid 2 to 168 .

\section{Recombination assays}

In vitro inversion and cleavage assays were performed as described previously (Haykinson and Johnson 1993). Incubations were typically for 3-4 min to measure reaction rates.

\section{Ligation assays}

Ligations were performed in a volume of $10 \mu$ l containing 50 mM HEPES ( $\mathrm{pH} 7.5$ ), $50 \mathrm{mM}$ potassium glutamate, $10 \mathrm{mM}$ magnesium acetate, and $1 \mathrm{~mm}$ ATP in the presence of $2 \mathrm{ng}$ of labeled DNA fragment and HU or HMG protein as indicated. After 10 min at $30^{\circ} \mathrm{C}, 0.6$ Weiss units of T4 DNA ligase (New England Biolabs/ was added and incubated for $10 \mathrm{~min}$ followed by inactivation of the ligase by shifting to $65^{\circ} \mathrm{C}$ for $15 \mathrm{~min}$. Some reactions were then incubated with 1 unit exonuclease III (Pharmacia) for $45 \mathrm{~min}$ at $37^{\circ} \mathrm{C}$ prior to incubation with $0.5 \%$ SDS and proteinase $\mathrm{K}(200 \mu \mathrm{g} / \mathrm{ml})$ for $20 \mathrm{~min}$. The samples were electrophoresed in a $7 \%$ polyacrylamide $(60: 1$ acrylamide : bis $)$ gel containing $10 \%$ glycerol in Tris-borate-EDTA buffer at $0.3-$ $0.5 \mathrm{~V} / \mathrm{cm}$ for $\sim 12 \mathrm{hrs}$. The electrophoretic migration of circular DNA molecules is slower relative to the linear species at lower currents. The identities of the bands seen in the ligation assays were confirmed, in part, by the method described in Dripps and Wartell (1987). Band intensities from autoradiographs were quantitated by densitometry, and Fourier transformation of the ligation data were performed as described in Haykinson and Johnson (1993).

\section{DNA-binding assays}

Filter binding assays were performed in the ligation buffer described above minus ATP by incubating different amounts of proteins with either 1 pmole of ${ }^{32} \mathrm{P}$-labeled Holliday structures or 0.1-0.5 pmole ${ }^{32}$ P-labeled 240-bp linear DNA in a $20-\mu l$ reaction volume. After $10 \mathrm{~min}$ at $23^{\circ} \mathrm{C}$, the solution was applied to a $0.1-\mu \mathrm{m}$ nitrocellulose filter (Schleicher \& Schuell) and washed in the same buffer. Protein/DNA-binding reactions for the mobility retardation assays were performed in the same buffer, and reaction products were electrophoresed in a $5 \%$ polyacrylamide gel at either $4^{\circ} \mathrm{C}$ or $23^{\circ} \mathrm{C}$ as described by Osuna et al. (1991). ${ }^{32} \mathrm{P}$-Labeled Holliday structures, formed by the annealing of 70 to 85-bp oligonucleotides representing the FLP recombination site, were generously provided to us by J. Dixon and P. Sadowski (University of Toronto, Canada).

\section{Acknowledgments}

We thank Julie Dixon and Paul Sadowski for their gift of Holliday DNA structures, and Michael Carey for his donation of HeLa nuclear extract. Mass spectra were collected by Ken Conklin and Kym Faull in the UCLA Center for Molecular and Medical Sciences Mass Spectrometry; amino acid analysis and amino-terminal amino acid sequencing were performed by $\mathrm{Au}$ dree Fowler and colleagues at the UCLA protein microsequencing facility. We are grateful to David Berger, Sydney Kustu, Anca Segall, Steven Goodman, Howard Nash, Ronald Chalmers, Nancy Kleckner, Brigitte Lavoie, and George Chaconas for sharing unpublished results. We also thank members of this laboratory for their helpful comments on the manuscript. This work was supported by National Institute of Health grant GM38509. T.T.P. was supported in part by a National Science Foundation Fellowship; M.J.H. was supported by a grant from the Jonsson Cancer Center Foundation.

The publication costs of this article were defrayed in part by payment of page charges. This article must therefore be hereby marked "advertisement" in accordance with 18 USC section 1734 solely to indicate this fact.

\section{References}

Adachi, Y., S. Mizuno, and M. Yoshida. 1990. Efficient largescale purification of non-histone chromosomal proteins HMG1 and HMG2 by using Polybuffer-exchanger PBE94. $I$. Chromatogr. 530: 39-46.

Adhya, S. 1989. Multipartite genetic control elements: Communication by DNA loop. Annu. Rev. Genet. 23: 227-250.

Alexandrova, E.A. and B.G. Beltchev. 1988. Acetylated HMG1 protein interacts specifically with homologous DNA polymerase alpha in vitro. Biochem. Biophys. Res. Comm. 154: 918-927.

Alexandrova, E.A., L.N. Marekov, and B.G. Beltchev. 1984. In- 
volvement of protein HMG1 in DNA replication. FEBS Lett. 178: $153-156$

Baker, T.A. and M. Mizuuchi. 1992. DNA-promoted assembly of the active tetramer of the Mu transposase. Genes \& Dev. 6: 2221-2232.

Baker, T.A., K. Sekimizu, B.E. Funnell, and A. Kornberg. 1986. Extensive unwinding of the plasmid template during staged enzymatic initiation of DNA replication for the origin of the Escherichia coli chromosome. Cell 45: 53-64.

Bellomy, G.R. and M.T. Record Jr. 1990. Stable DNA loops in vivo and in vitro: Roles in gene regulation at a distance and in biophysical characterization of DNA. Prog. Nucleic Acid Res. Mol. Biol. 39: 81-127.

Bianchi, M.E., M. Beltrame, and G. Paonessa. 1989. Specific recognition of cruciform DNA by nuclear protein HMGl. Science 243: 1056-1058.

Bianchi, M.E., L. Falciola, S. Ferrari, and D.M.J. Lilley. 1992. The DNA binding site of HMGl protein is composed of two similar segments (HMG boxes), both of which have counterparts in other eukaryotic regulatory proteins. $E M B O J$. 11: 1055-1063.

Bonne-Andrea, C., F. Harper, J. Sobczak, and A-M. De Recondo. 1984. Rat liver HMG1: A physiological nucleosome assembly factor. EMBO I. 3: 1193-1 199.

Briggs, M.R., J.T. Kadonaga, S.P. Bell, and R. Tjian. 1986. Purification and biochemical characterization of the promoterspecific transcription factor, Spl. Science 234: 47-52.

Brown, J.W. and J.A. Anderson. 1986. The binding of the chromosomal protein HMG-2a to DNA regions of reduced stabilities. J. Biol. Chem. 261: 1349-1354.

Bustin, M., D. Lehn, and D. Landsman. 1990 Structural features of the HMG chromosomal proteins and their genes. Biochim. Biophys. Acta 1049: 231-243.

Butler, A.P., J.K.W. Mardian, and D.E. Olins. 1985. Nonhistone chromosomal protein HMGl interactions with DNA. J. Biol. Chem. 260: 10613-10620.

Carballo, M., P. Puigdomenech, and J. Palau. 1983. DNA and histone $\mathrm{HI}$ interact with different domains of HMG1 and HMG2 proteins. EMBO I. 2: 1759-1764.

Carballo, M., P. Puigdomenech, T. Tancredi, and J. Palau. 1984. Interaction between domains in chromosomal protein HMG-1. EMBO I. 3: 1255-1261.

Craigie, R., D.J. Arndt-Jovin, and K. Mizuuchi. 1985. A defined system for the DNA strand-transfer reaction at the initiation of bacteriophage $\mathrm{Mu}$ transposition: Protein and DNA substrate requirements. Proc. Natl. Acad. Sci. 82: 7570-7574.

Diffley, J.F.X. and B. Stillman. 1991. A close relative of the nuclear, chromosomal high-mobility group protein HMG1 in yeast mitochondria. Proc. Natl. Acad. Sci. 88: 7864-7868.

- 1992. DNA binding properties of an HMG1-related protein from yeast mitochondria. I. Biol. Chem. 267: 33683374.

Dignam, J.D., P.L. Martin, B.S. Shastry, and R.G. Roeder. 1983. Eukaryotic gene transcription with purified components. Methods Enzymol. 101: 582-598.

Dixon, N.E. and A. Kornberg. 1984. Protein HU in the enzymatic replication of the chromosomal origin of Escherichia coli. Proc. Natl. Acad. Sci. 81: 424-428.

Dripps, D. and R.M. Wartell. 1987. DNA bending induced by the catabolite activator protein allows ring formation of a 144 bp DNA. J. Biomol. Struct. Dynam. 5: 1-13.

Drlica, K. and J. Rouvière-Yaniv. 1987. Histonelike proteins of bacteria. Microbiol. Rev. 51: 301-319.

Echols, H. 1986. Multiple DNA-protein interactions governing high-precision DNA transactions. Science 233: 1050-1056.

Ferrari, S., V.R. Harley, A. Pontiggia, P.N. Goodfellow, R. Lov-
ell-Badge, and M.E. Bianchi. 1992. SRY, like HMGl, recognizes sharp angles in DNA. EMBO J. 11: 4497-4506.

Fisher, R.P., T. Lisowsky, M.A. Parisi, and D.A. Clayton. 1992. DNA wrapping and bending by a mitochondrial high mobility group-like transcriptional activator protein. J.Biol. Chem. 267: 3358-3367.

Giese, K., A. Amsterdam, and R. Grosschedl. 1991. DNA-binding properties of the HMG domain of the lymphoid-specific transcriptional regulator LEF-1. Genes \& Dev. 5: 2567-2578.

Giese, K., J. Cox, and R. Grosschedl. 1992. The HMG domain of lymphoid enhancer factor 1 bends DNA and facilitates assembly of functional nucleoprotein structures. Cell 69: 185-195.

Glasgow, A.C., K.T. Hughes, and M.I. Simon. 1989. Bacterial DNA inversion systems. In Mobile DNA /ed. D.E. Berg and M.M. Howel, pp. 637-659. American Society for Microbiology, Washington, D.C.

Gober, J.W. and L. Shapiro. 1990. Integration host factor is required for the activation of developmentally regulated genes in Caulobacter. Genes \& Dev. 4: 1494-1504.

Goodman, S.D. and H.A. Nash. 1989. Functional replacement of a protein-induced bend in a recombination site. Nature 341: 251-254.

Goodman, S.D., S.C. Nicholson, and H.A. Nash. 1992. Deformation of DNA during site-specific recombination of bacteriophage $\lambda$ : Replacement of IHF protein by HU protein or sequence-directed bends. Proc. Natl. Acad. Sci. 89: 11910 11914.

Goodwin, G.H., C. Sanders, and E.W. Johns. 1973. A new group of chromatin-associated proteins with a high content of acidic and basic amino acids. Eur. J. Biochem. 38: 14-19.

Goodwin, G.H., K.V. Shooter, and E.W. Johns. 1975. Interaction of non-histone chromatin protein (high-mobility group protein 2) with DNA. Eur. J. Biochem. 54: 427-433.

Hagerman, P.J. 1992. Straightening out the bends in curved DNA. Biochim. Biophys. Acta 1131: 125-132.

Haykinson, M.H. and R.C. Johnson. 1993. DNA looping and the helical repeat in vitro and in vivo: Effect of HU protein and enhancer location on Hin invertasome assembly. EMBO $I$. 12: 2503-2512.

Heichman, K.A. and R.C. Johnson. 1990. The Hin invertasome: Protein-mediated joining of distant recombination sites at the enhancer. Science 249: 511-517.

Heichman, K.A., I.P.G. Moskowitz, and R.C. Johnson. 1991. Configuration of DNA strands and mechanism of strand exchange in the Hin invertasome as revealed by analysis of recombinant knots. Genes \& Dev. 5: 1622-1634.

Hodges-Garcia, Y., P.J. Hagerman, and D.E. Pettijohn. 1989. DNA ring closure mediated by protein HU. J. Biol. Chem. 264: $14621-14623$.

Hoover, T.R., E. Santero, S. Porter, and S. Kustu. 1990. The integration host factor stimulates interaction of RNA polymerase with NIFA, the transcriptional activator for nitrogen fixation operons. Cell 63: 11-22.

Huisman, R., M. Faelen, D. Girard, A. Jaffé, A. Toussaint, and J. Rouvière-Yaniv. 1989. Multiple defects in Escherichia coli mutants lacking HU protein. J. Bacteriol. 171: 3704-3712.

Jantzen, H., A. Admon, S.P. Bell, and R. Tiian. 1990. Nucleolar transcription factor hUBF contains a DNA-binding motif with homology to HMG proteins. Nature 344: 830-836.

Javaherian, K., M. Sadeghi, and L.F. Liu. 1979. Nonhistone proteins $\mathrm{HMG}_{1}$ and $\mathrm{HMG}_{2}$ unwind DNA double helix. Nucleic Acids Res. 6: 3569-3580.

Johns, E.W. 1982. The HMG chromosomal proteins. Academic Press, New York.

Johnson, R.C. 1991. Mechanism of site-specific DNA inversion in bacteria. Curr. Opin. Genet. Dev. 1: 404-411. 
Johnson, R.C. and M.F. Bruist. 1989. Intermediates in Hin-mediated DNA inversion: A role for Fis and the recombinational enhancer in the strand exchange reaction. EMBO $J$. 8: $1581-1590$.

Johnson, R.C., M.F. Bruist, and M.I. Simon. 1986. Host protein requirements for in vitro site-specific DNA inversion. Cell 46: 531-539.

Kanaar, R., A. Klippel, E. Shekhtman, J.M. Dungan, R. Kahmann, and N.R. Cozzarelli. 1990. Processive recombination by the phage $\mathrm{Mu}$ Gin system: implications for the mechanism of DNA strand exchange, DNA site alignment, and enhancer action. Cell 62: 353-366.

Kim, S., L. Moitoso de Vargas, S.E. Nunes-Düby, and A. Landy. 1990. Mapping of a higher order protein-DNA complex: Two kinds of long-range interactions in $\lambda$ attL. Cell 63: 773-781.

Kaplan, D.J. and C.H. Duncan. 1988. Full length cDNA sequence for bovine high mobility group 1 (HMG1) protein. Nucleic Acids Res. 16: 10375.

Kohlstaedt, L.A., E.C. Sung, A. Fujishige, and R.D. Cole. 1987. Non-histone chromosomal protein HMGl modulates the histone $\mathrm{H} 1$-induced condensation of DNA. I. Biol. Chem. 262: 524-526.

Kotlarz, D., A. Fritsch, and H. Buc. 1986. Variations of intramolecular ligation rates allow the detection of protein-induced bends in DNA. EMBO I. 5: 799-803.

Kuehl, L., B. Salmond, and L. Tran. 1984. Concentrations of high-mobility-group proteins in the nucleus and cytoplasm of several rat tissues. J. Cell Biol. 99: 648-654.

Lavoie, B.D. and G. Chaconas. 1990. Immunoelectron microscopic analysis of the A, B, and $\mathrm{HU}$ protein content of bacteriophage $\mathrm{Mu}$ transpososomes. I. Biol. Chem. 265: 16231627.

Lilley, D.M.J. 1992. HMG has DNA wrapped up. Nature 357: 282-283.

Moitoso de Vargas, L., S. Kim, and A. Landy. 1989. DNA looping generated by DNA bending protein IHF and the two domains of lambda integrase. Science 244: 1457-1461.

Morisato, D. and N. Kleckner. 1987. Tn10 transposition and circle formation in vitro. Cell 51: 101-111.

Osuna, R., S.E. Finkel, and R.C. Johnson. 1991. Identification of two functional regions in Fis: The $\mathrm{N}$-terminus is required to promote Hin-mediated DNA inversion but not $\lambda$ excision. EMBO /. 10: 1593-1603.

Pettijohn, D.E. 1988. Histone-like proteins and bacterial chromosome structure. J. Biol. Chem. 263: 12793-12796.

Pil, P.M. and S.J. Lippard. 1992. Specific binding of chromosomal protein HMG1 to DNA damaged by the anticancer drug cisplatin. Science 256: 234-237.

Pontiggia, A., A. Negri, M. Beltrame, and M.E. Bianchi. 1993. Protein HU binds specifically to kinked DNA. Mol. Microbiol. 7: 343-350.

Ptashne, M. 1986. Gene regulation by proteins acting nearby and at a distance. Nature 322: 697-701.

Reeck, G.R., P.J. Isackson, and D.C. Teller. 1982. Domain structure in high molecular weight high mobility group nonhistone chromatin proteins. Nature 300: 76-78.

Richet, E., P. Abcarian, and H.A. Nash. 1986. The interaction of recombination proteins with supercoiled DNA: Defining the role of supercoiling in lambda integrative recombination. Cell 46: 1011-1021.

Richmond, T.J., J.T. Finch, B. Rushton, D. Rhodes, and A. Klug. 1984. Structure of the nucleosome core particle at $7 \AA$ resolution. Nature 311: 532-537.

Robertson, C., and H.A. Nash. 1988. Bending of the bacteriophage $\lambda$ attachment site by Escherichia coli integration host factor. J. Biol. Chem. 263: 3554-3557.
Rouvière-Yaniv, J., J. Germond, and M. Yaniv. 1979. E. coli DNA binding protein $\mathrm{HU}$ forms nucleosome-like structures with circular double-stranded DNA. Cell 17: 265-274.

Russnak, R.H., E.P.M. Candido, and C.R. Astell. 1988. Interaction of the mouse chromosomal protein HMG-I with the $3^{\prime}$ ends of genes in vitro. J. Biol. Chem. 263: 6392-6399.

Schroth, G.P., G.R. Cook, E.M. Bradbury, and J.M. Gottesfeld. 1989. Transcription factor IIIA induced bending of the $\mathrm{Xe}$ nopus somatic $5 S$ gene promoter. Nature 340: 487-488.

Shastri, K., P.J. Isackson, J.L. Fishback, M.D. Land, and G.R. Reeck. 1982. Influence of non-histone chromatin protein HMG-1 on the enzymatic digestion of purified DNA. $\mathrm{Nu}$ cleic Acids Res. 10: 5059-5072.

Sheflin, L.G. and S.W. Spaulding. 1989. High mobility group protein 1 preferentially conserves torsion in negatively supercoiled DNA. Biochemistry 28: 5658-5664.

Shooter, K.V., G.H. Goodwin, and E.W. Johns. 1974. Interactions of a purified non-histone chromosomal protein with DNA and histone. Eur. I. Biochem. 47: 263-270.

Shore, D., J. Langowski, and R.L. Baldwin. 1981. DNA flexibility studied by covalent closure of short fragments into circles. Proc. Natl. Acad. Sci. 78: 4833-4837.

Singh, J. and G.H. Dixon. 1990. High mobility group proteins 1 and 2 function as general class II transcription factors. Biochemistry 29: 6295-6302.

Skarstad, K., T.A. Baker, and A. Kornberg. 1990. Strand separation required for initiation of replication at the chromosomal origin of $E$. coli is facilitated by a distant RNA-DNA hybrid. $E M B O$ /. 9: 2341-2348.

Solomon, M.J., F. Strauss, and A. Varshavsky. 1986. A mammalian high mobility group protein recognizes any stretch of six A-T base pairs in duplex DNA. Proc. Natl. Acad. Sci. 83: 1276-1280.

Stenzel, T.T., T. MacAllister, and D. Bastia. 1991. Cooperativity at a distance promoted by the combined action of two replication initiator proteins and a DNA bending protein at the replication origin of pSC101. Genes \& Dev. 5: 1453-1463.

Stoute, J.A. and W.F. Marzluff. 1982. HMG-proteins 1 and 2 are required for transcription of chromatin by endogenous RNA polymerase. Biochem. Biophys. Res. Comm. 107: 12791284.

Thanos, D. and T. Maniatis. 1992. The high mobility group protein $\mathrm{HMG} \mathrm{I}(\mathrm{Y})$ is required for NF- $\mathrm{kB}$-dependent virus induction of the human IFN- $\beta$ gene. Cell 71: 777-789.

Thompson, J.F. and A. Landy. 1988. Empirical estimation of protein-induced DNA bending angles: Applications to sitespecific recombination complexes. Nucleic Acids Res. 16: 9687-9705.

Travers, A.A. and A. Klug. 1990. Bending of DNA in nucleoprotein complexes. In DNA topology and its biological effects (ed. N.R. Cozzarelli and J.C. Wang), pp. 57-106. Cold Spring Harbor Laboratory Press, Cold Spring Harbor, New York.

Tremethick, D.J. and P.L. Molloy. 1986. High mobility group proteins 1 and 2 stimulate transcription in vitro by RNA polymerases II and III. J. Biol. Chem. 261: 6986-6992.

. 1988. Effects of high mobility group proteins 1 and 2 on initiation and elongation of specific transcription by RNA polymerase II in vitro. Nucleic Acids Res. 16: 11107-11123.

Wada, M., Y. Kano, T. Ogawa, T. Okazaki, and F. Imamoto. 1988. Construction and characterization of the deletion mutant of hupA and hupB genes in Escherichia coli. J. Mol. Biol. 204: 581-591.

Weir, H.M., P.J. Kraulis, C.S. Hill, A.R.C. Raine, E.D. Laue, and J.O. Thomas. 1993. Structure of the HMG box motif in the B-domain of HMG1. EMBO /. 12: 1311-1319.

Wen, L., J.K. Huang, B.H. Johnson, and G.R. Reeck. 1989. A 
Paull et al.

human placental cDNA clone that encodes nonhistone chromosomal protein HMG-1. Nucleic Acids Res. 17: 11971214.

Wright, J.M. and G.H. Dixon. 1988. Induction by torsional stress of an altered DNA conformation 5' upstream of the gene for a high mobility group protein from trout and specific binding to flanking sequences by the gene product HMG-T. Biochemistry 27: 576-581.

Wu, H.M. and D.M. Crothers. 1984. The locus of sequencedirected and protein-induced DNA bending. Nature 308: 509-513.

Yang, C. and H.A. Nash. 1989. The interaction of E. coli IHF protein with its specific binding sites. Cell 57: 869-880.

Yoshida, M. 1987. High glutamic and aspartic region in nonhistone protein HMG $(1+2)$ unwinds DNA double helical structure. I. Biochem. 101: 175-180.

Zahn, K. and F.R. Blattner. 1987. Direct evidence for DNA bending at the lambda replication origin. Science 236: 416-422. 


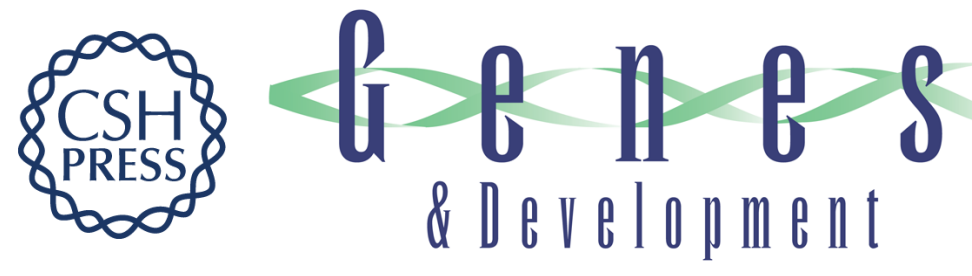

\section{The nonspecific DNA-binding and -bending proteins HMG1 and HMG2 promote the assembly of complex nucleoprotein structures.}

T T Paull, M J Haykinson and R C Johnson

Genes Dev. 1993, 7:

Access the most recent version at doi:10.1101/gad.7.8.1521

References This article cites 88 articles, 32 of which can be accessed free at: http://genesdev.cshlp.org/content/7/8/1521.full.html\#ref-list-1

License

Email Alerting

Service

Receive free email alerts when new articles cite this article - sign up in the box at the top right corner of the article or click here.

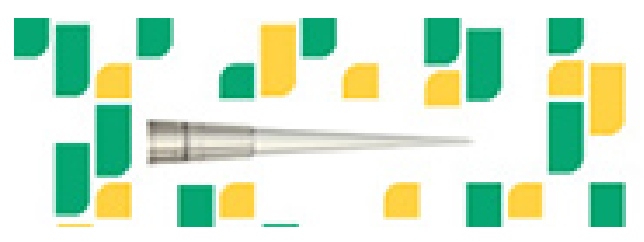

Focused on your science. 